\title{
KEMAMPUAN KONEKSI MATEMATIS SISWA DALAM MEMECAHKAN MASALAH MATEMATIKA DITINJAU DARI ADVERSITY QUOTIENT
}

\author{
Jumrotul Mafulah \\ Pendidikan Matematika, FMIPA, Universitas Negeri Surabaya, email: jumrotulmafulah16030174085@mhs.unesa.ac.id
}

\section{Siti Maghfirotun Amin}

Pendidikan matematika, FMIPA, Universitas Negeri Surabaya, email: sitiamin@unesa.ac.id

\begin{abstract}
Abstrak
Kemampuan koneksi matematis merupakan salah satu kemampuan yang diperlukan dalam memecahkan masalah matematika. Dalam memecahkan masalah, setiap siswa memiliki cara yang berbeda dalam menyelesaikannya. Hal tersebut dikarenakan, setiap siswa memiliki kecerdasan berbeda dalam menyelesaikan masalah. Kecerdasan ini dikenal dengan Adversity Quotient (AQ). Terdapat tiga tingkatan AQ yaitu climbers, campers, dan quitters. Penelitian ini bertujuan untuk mendeskripsikan kemampuan koneksi matematis siswa dalam memecahkan masalah matematika ditinjau dari AQ. Penelitian ini merupakan penelitian deskriptif dengan pendekatan kualitatif yang dilaksanakan di Kelas IX MTs Negeri Gresik yang terdiri atas tiga siswa yang memiliki tingkatan AQ berbeda. Instrumen penelitian yang digunakan terdiri atas angket Adversity Response Profile (ARP), Tes Pemecahan Masalah (TPM) dan pedoman wawancara. Hasil pada penelitian ini menunjukkan bahwa: pada tahap memahami masalah, subjek climbers dan campers dapat menceritakan kembali dengan bahasanya sendiri berbeda dengan subjek quitters yang mengubah bahasa soal dengan arti yang berbeda, pada tahap menyusun rencana, subjek climbers memahami keterkaitan masalah dengan konsep matematika dan kehidupan sehari-hari serta menyusun rencana dengan cukup runtut dan jelas sedangkan subjek campers dan quitters memahami keterkaitan masalah dengan konsep matematika dan kehidupan sehari-hari serta menyusun rencana dengan cukup baik, pada tahap melaksanakan rencana, subjek climbers dan campers dapat menemukan jawaban yang benar sedangkan subjek quitters menemukan jawaban yang belum benar, pada tahap melihat kembali, subjek climbers melakukan pengecekan kembali sehingga dapat memberikan kesimpulan yang tepat sedangkan subjek campers dan quitters tidak melakukan pengecekan kembali namun dapat memberikan kesimpulan yang cukup tepat.
\end{abstract}

Kata Kunci: kemampuan koneksi matematis, masalah matematika, memecahkan masalah, adversity quotient

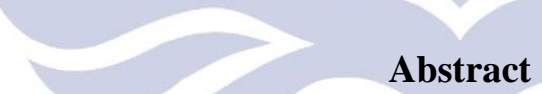

Mathematical connection ability is one of the abilities needed in solving mathematical problems. In solving problems, each student has a different way of solving it. This is due to the variety of intelligence that the students possess. This intelligence is known as Adversity Quotient (AQ). There are three levels of AQ namely climbers, campers, and quitters. This study aimed to describe the students' mathematical connections ability in solving mathematical problems related to their AQ. This research is a descriptive study with a qualitative approach carried out in Class IX of MTs Negeri Gresik consisting of three students who have different levels of AQ. The research instrument used consisted of the Adversity Response Profile (ARP) questionnaire, problem solving Test, and interview guidelines. The results of this study indicate that: at the stage of understanding the problem, climbers and campers subjects could retell with their language different from quitters subjects who change the language of questions with different meanings, at the stage of preparing a plan, climbers subjects understand the relationship of problems with mathematical concepts and life everyday and plan quite coherently and clearly while campers and quitters subjects understand the relationship of problems with mathematical concepts and everyday life and plan quite well, at the stage of implementing the plan, climbers and campers subjects could find the right answers while quitters subjects find the answers that are not yet correct, in the stage of looking back, climbers subjects do the checking again so that they could give the right conclusions while the campers and quitters subjects do not do the checks again but could provide conclusions that are quite precise.

Keywords: Mathematical connection ability, mathematical problems, problem solving, adversity quotient 


\section{PENDAHULUAN}

Matematika sebagai salah satu mata pelajaran wajib yang diajarkan mulai dari jenjang pendidikan dasar hingga jenjang perguruan tinggi (Umami, 2015). Hal ini berarti matematika penting untuk diajarkan pada setiap jenjang pendidikan. Salah satu tujuan mata pelajaran matematika diajarkan pada jenjang pendidikan sekolah menengah ialah agar siswa dapat memahami konsep matematika. Memahami konsep matematika mencakup kompetensi menjelaskan keterkaitan antarkonsep dan menggunakan konsep ataupun algoritma dalam pemecahan masalah (Subchan, dkk., 2018). Dengan menjelaskan keterkaitan antarkonsep dalam matematika siswa dapat memahami bahwa matematika merupakan konsep yang utuh, bukan terpisah-pisah, melainkan berhubungan antara satu konsep dengan konsep yang lain. Menurut James (dalam Hidayat, 2018) yang menyatakan bahwa matematika merupakan ilmu tentang logika yang terdiri atas bentuk, susunan, besaran, dan konsep-konsep yang berhubungan satu dengan yang lain. Selain siswa mampu mengkaitkan antarkonsep, siswa juga dapat memahami konsep matematika dalam memecahkan masalah matematika (Pradika, dkk., 2019).

Untuk mencapai tujuan mata pelajaran matematika tersebut, siswa memerlukan kemampuan dalam mengoneksikan antarkonsep dalam matematika ataupun di luar matematika, baik di cabang ilmu yang lain maupun di kehidupan sehari-hari. Kemampuan ini dikenal sebagai kemampuan koneksi matematis. Kemampuan koneksi matematis merupakan kesanggupan seorang siswa dalam mencari keterkaitan konsep dan prosedur, memahami antar topik matematika, dan kemampuan siswa mengaplikasikan konsep matematika dalam bidang lain atau dalam kehidupan sehari-hari (Putri, 2017). Keterkaitan konsep dan prosedur yang dimaksud ialah keterkaitan pengetahuan konseptual dan pengetahuan prosedural. Dolores-Flores, dkk. (2018) menyebutkan bahwa pengetahuan prosedural dan konseptual memainkan peran penting dalam koneksi matematika, yang keduanya berkorelasi positif. Korelasi ini dapat dikembangkan melalui instruksi dan meningkatkan pemahaman matematika mereka. Ini berarti adanya kemampuan koneksi matematis siswa dalam pembelajaran matematika, membuat siswa memiliki pemahaman konsep yang lebih mendalam dan bertahan lebih lama.

Fendrik (2019) merujuk pada National Council of Teachers of Mathematics (NCTM) mengemukakan bahwa tanpa kemampuan koneksi matematis, siswa harus belajar mengingat banyak konsep dalam matematika dan ketika siswa mampu menghubungkan suatu konsep ke konsep yang lain, maka mereka memiliki pandangan bahwa matematika sebagai ilmu yang utuh bukan terpisah-pisah.
Berdasarkan pernyataan tersebut kemampuan koneksi matematis bermanfaat bagi siswa dalam memperluas wawasan siswa, melihat matematika sebagai satu kesatuan yang utuh, serta mengenal hubungan dan manfaat matematika dengan bidang lain.

Terdapat kriteria tertentu yang menjadi ciri bahwa siswa melakukan koneksi matematis. Kriteria inilah yang disebut dengan indikator koneksi matematis siswa. NCTM (2000) menguraikan indikator koneksi matematis ke dalam tiga komponen besar yaitu (1) Mengenali dan menggunakan hubungan antar ide-ide dalam matematika (2) Memahami keterkaitan ide-ide matematika dan membentuk ide matematika baru yang lain sehingga menghasilkan suatu keterkaitan yang menyeluruh (3) Mengenali dan mengaplikasikan satu konten matematika ke dalam konten matematika lain dan ke lingkungan di luar matematika.

Untuk mengetahui apakah siswa menunjukkan indikator tersebut, siswa perlu diberikan suatu permasalahan matematika untuk diselesaikan. Menurut Pradika, dkk. (2019) dalam memecahkan masalah matematika, siswa yang memiliki kemampuan koneksi matematis lebih mudah menyelesaikan masalah yang sulit. Seorang siswa tidak hanya membutuhkan kemampuan kognitif untuk memahami dan mewakili situasi masalah, membuat algoritma, memproses berbagai jenis informasi, dan melaksanakan perhitungan, tetapi juga harus dapat mengidentifikasi dan mengelola beberapa metode untuk menyelesaikan masalah

Masalah matematika erat kaitannya dengan pemecahan masalah (problem solving). Bell (dalam Chairani, 2016), menjelaskan bahwa pemecahan masalah membantu siswa untuk meningkatkan kemampuan menganalisis dan menggunakan penyelesaian masalah dalam situasi yang berbeda, pemecahan masalah juga membantu siswa dalam belajar tentang fakta, skill, konsep, dan prinsip matematika melalui ilustrasi aplikasi objek-objek matematika dan kaitan antar objek-objek tersebut.

Polya (1973) juga mengemukakan bahwa pemecahan masalah adalah suatu usaha mencari jalan keluar dari suatu tujuan yang tidak begitu mudah dalam pencapaiannya. Beliau juga menjelaskan bahwa terdapat empat tahap dalam memecahkan masalah yaitu: (1) memahami masalah, (2) menyusun rencana, (3) melaksanakan rencana, dan (4) melihat kembali. Dalam langkah memahami masalah, siswa harus dapat memahami masalah yang ada dengan cara menentukan dan mencari apa yang diketahui dan apa yang ditanyakan dalam masalah. Dalam menyusun rencana, siswa harus dapat merancang rencana dari masalah yang ada berdasarkan apa yang telah diketahui dan yang ditanyakan masalah sesuai dengan langkah pertama. Dalam 
melaksanakan rencana, siswa harus dapat menyelesaikan masalah yang ada sesuai dengan perencanaan yang telah dibuat pada langkah kedua. Pada langkah melihat kembali hasil yang telah diperoleh, siswa harus dapat memeriksa kembali hasil yang telah diperoleh, apakah jawabannya benar dan sesuai dengan apa yang ditanyakan pada masalah tersebut. (Hasan, 2019)

Pemecahan masalah perlu dilakukan oleh setiap individu dalam menyelesaikan masalah yang mereka hadapi. Setiap individu memiliki cara tersendiri dalam menyikapi suatu permasalahan dan tentunya sikap individu ketika dihadapkan masalah akan berbeda dengan sikap yang dimiliki individu lain. Kemampuan memecahkan masalah siswa berbeda-beda dipengaruhi oleh kemampuan berpikir mereka (Sari, dkk., 2019). Selain itu, Hal tersebut dipengaruhi oleh hasrat atau keinginan yang dimiliki setiap individu. Hasrat atau keinginan yang dimaksud ini ialah hasrat dalam mengatasi rintangan. Berkaitan dengan hasrat tersebut, menurut Megaton \& Tarmizi (2010) setiap individu telah dibekali potensi kecerdasan yang dikenal dengan Adversity Quotient.

Adversity Quotient (AQ) merupakan konsep baru tentang jenis kecerdasan yang diperkenalkan oleh Paul G. Stoltz, seorang doktor psikologi Amerika (Mawardhiyah \& Manoy, 2018). Adversity Quotient (AQ) adalah kecerdasan untuk mengatasi kesulitan. Stoltz (1997) mengumpamakan suatu masalah sebagai suatu kegiatan pendakian gunung dan menjelaskan AQ memiliki tiga komponen yaitu (1) kerangka kerja konseptual baru untuk memahami dan meningkatkan semua bentuk keberhasilan, (2) ukuran bagaimana seseorang menghadapi masalah, dan (3) seperangkat alat yang diatur secara ilmiah untuk meningkatkan cara seseorang dalam merespons kesulitan.

Stoltz (1997) mengategorikan AQ ke dalam tiga tingkatan yaitu: climbers (AQ tinggi), campers (AQ sedang), dan quitters (AQ rendah). Climbers merupakan tipe manusia yang mau berjuang, selalu optimis, selalu melihat peluang diantara celah, melihat setitik harapan dibalik keputusasaan, tidak mempedulikan sebesar apapun kesulitan yang datang dan selalu bergairah untuk maju. Campers merupakan tipe manusia yang puas dengan mencukupkan diri, memilih berhenti meskipun masih ada kesempatan untuk lebih berkembang lagi, dan tidak mau berjuang untuk hal-hal yang beresiko tinggi. Sedangkan quitters merupakan tipe manusia yang mudah menyerah dalam menghadapi kesulitan (Setyaningsih \& Prihatnani, 2018). Dengan adanya pengelompokan climbers, campers, dan quitters, seseorang dapat diprediksi bagaimana ia menyikapi masalah matematika.

Dengan adanya pengelompokan climbers, campers, dan quitters, seseorang dapat diprediksi bagaimana seorang tersebut menyikapi masalah matematika. Hal ini diperkuat dalam penelitian yang dilakukan oleh Irianti (2017) tentang proses pemecahan masalah matematika siswa berdasarkan Adversity Quontient, ia menjelaskan bahwa siswa climbers secara tanggap dan tepat dalam memecahkan masalah matematika bahkan mereka dapat memberikan alternatif jawaban dari permasalah yang diberikan, siswa campers mampu menyusun rencana dalam memecahkan masalah matematika namun belum dapat menemukan jawaban akhir, sedangkan siswa quitters hanya mampu melakukan tahap awal dalam pemecahan masalah yaitu mengumpulkan informasi dalam permasalahan yang diberikan. Namun dalam penelitian yang dilakukakan Irianti hanya mengkaitkan AQ dalam memecahkan masalah matematika belum mengkaitkan AQ dalam kemampuan koneksi matematis siswa.

Berdasarkan penjelasan di atas, peneliti tertarik untuk melakukan penelitian tentang kemampuan koneksi matematis siswa dalam memecahkan masalah matematika ditinjau dari Adversity Quontient yang bertujuan untuk mendeskripsikan kemampuan koneksi matematis siswa climbers, campers, dan quitters dalam menyelesaikan masalah matematika.

\section{METODE}

Jenis penelitian ini termasuk penelitian deskriptif kualitatif yang dirancang untuk memahami dan menggambarkan suatu fenomena dengan cara mendeskripsikan kemampuan tentang koneksi matematis siswa dalam memecahkan masalah matematika ditinjau dari Adversity Quotient dalam bentuk kata-kata dan bahasa. Secara garis besar, rancangan penelitian dilakukan melalui empat tahap, yaitu: (1) tahap persiapan, meliputi menelaah teori dan penyusunan instrumen penelitian, (2) tahap pemilihan subjek, (3) tahap pengumpulan data, dan (4) tahap analisis data.

Untuk memeroleh data, peneliti sebagai instrumen utama dalam penelitian ini sedangkan instrumen pendukung penelitian ini ada tiga yaitu angket berupa Adversity Profile Response (ARP) untuk memilih subjek penelitian, tes berupa Tes Pemecahan Masalah (TPM) yang menggunakan materi kesebangunan bangun datar sebanyak 1 soal, dan wawancara untuk memeroleh informasi yang mendalam tentang kemampuan koneksi matematis siswa dalam memecahkan masalah matematika.

ARP yang dibagikan kepada siswa merupakan hasil adopsi ARP oleh Sudarman (2011) dalam penelitian beliau. Alasan peneliti memilih adopsi ARP milik Sudarman ialah kesesuaian target angket ARP milik Sudarman dengan target angket ARP peneliti yang akan dibagikan yaitu siswa SMP. Selain itu, angket ARP milik Sudarman merupakan hasil adaptasi ARP oleh Stoltz 
(2000) dan sudah layak melalui uji validasi. Data hasil angket ARP dianalisis berdasarkan pedoman penskoran Stoltz (2000) dengan memberikan skor setiap butir pernyataan kemudian menjumlahkan skor setiap pernyataan agar diperoleh skor ARP. Skor ARP digunakan untuk menggolongkan siswa ke dalam lima tingkatan AQ, dengan ketentuan seperti pada Tabel 1. Agar dapat diidentifikasi perbedaan secara mudah dan jelas, dalam penelitian ini kategori tingkat AQ yang digunakan ada tiga yaitu quitters, campers, dan climbers.

Tabel 1. Kategori Tingkat AQ Berdasarkan Skor ARP

\begin{tabular}{|c|l|}
\hline \multicolumn{1}{|c|}{ Skor } & \multicolumn{1}{|c|}{ Kategori Tingkat AQ } \\
\hline 59 ke bawah & Quitters (QT) \\
\hline $60-94$ & $\begin{array}{l}\text { Peralihan quitters (QT) menuju campers } \\
(\mathrm{CP})\end{array}$ \\
\hline $95-134$ & Campers $(\mathrm{CP})$ \\
\hline $135-165$ & $\begin{array}{l}\text { Peralihan campers }(\mathrm{CP}) \text { menuju climbers } \\
(\mathrm{CB})\end{array}$ \\
\hline 166 ke atas & Climbers $(\mathrm{CB})$ \\
\hline
\end{tabular}

(Stoltz,2000)

TPM terdiri dari 1 soal berupa permasalahan dalam kehidupan sehari-hari yang berkaitan dengan materi kesebangunan bangun datar yang menuntut jawaban uraian. Pemilihan materi kesebangunan bangun datar berdasarkan pertimbangan bahwa materi tersebut memuat beberapa konsep-konsep matematika di SMP seperti transformasi geometri, perbandingan dan bangun datar sehingga siswa lebih berpeluang dalam mengkoneksikan pengetahuan yang mereka pelajari sebelumnya.TPM yang digunakan dalam penelitian ini, dibuat peneliti dengan mengadaptasi dari buku kurikulum 2013 revisi 2019 kelas IX. Berikut permasalahan yang peneliti sajikan dalam TPM untuk subjek penelitian.

"Ivan Gunawan atau biasa dikenal dengan Igun merupakan desainer terkenal di Indonesia. Selain berkerja sebagai desainer, ia juga memiliki usaha konveksi. Bahan yang diperlukan untuk memproduksi sebuah baju ialah kain dan benang. Untuk mengetahui biaya produksi yang dibutuhkan sebelum memproduksi dalam jumlah besar, ia membuat sampel baju ukuran kecil terlebih dahulu. Ternyata sampel tersebut memerlukan kain sekitar 0,25 $\mathrm{m}^{2}$ dan benang sekitar $300 \mathrm{~cm}$. Panjang dan lebar kain yang digunakan pada sampel berturut-turut adalah 1/4 dari panjang dan lebar kain dengan ukuran sebenarnya. Jika harga benang Rp.10.000,00/gulung dengan panjang 1000 meter dan harga kain Rp. $25.000 / \mathrm{m}^{2}$, berapa biaya produksi yang dibutuhkan Igun untuk memproduksi baju tersebut sebanyak 1000 baju?"
Data hasil TPM dianalisis dengan menyesuaikan jawaban subjek berdasarkan indikator kemampuan koneksi matematis yang dikembangkan peneliti berdasarkan indikator kemampuan konesi matematis oleh Hendriana dkk. (2017). Pada penelitian ini, terdapat sembilan indikator yang disajikan pada tabel berikut.

Tabel 2. Indikator Kemampuan Koneksi Matematis dalam Memecahkan Masalah

\begin{tabular}{|c|c|}
\hline $\begin{array}{c}\text { Tahap Pemecahan } \\
\text { Masalah }\end{array}$ & $\begin{array}{c}\text { Indikator Kemampuan Koneksi } \\
\text { Matematis }\end{array}$ \\
\hline $\begin{array}{l}\text { Memahami Masalah } \\
\text { (understanding } a \\
\text { problems) }\end{array}$ & $\begin{array}{l}\text { Dapat merepresentasikan masalah } \\
\text { ke bentuk representasi yang } \\
\text { ekuivalen. }\end{array}$ \\
\hline \multirow[t]{4}{*}{$\begin{array}{l}\text { Menyusun Rencana } \\
\text { (devising a plan) }\end{array}$} & $\begin{array}{l}\text { Dapat menjelaskan konsep } \\
\text { matematika yang berhubungan } \\
\text { dengan masalah. }\end{array}$ \\
\hline & $\begin{array}{l}\text { Dapat menjelaskan konsep disiplin } \\
\text { ilmu lain yang berkaitan dengan } \\
\text { masalah. }\end{array}$ \\
\hline & $\begin{array}{l}\text { Dapat menuliskan/menjelaskan } \\
\text { langkah-langkah penyelesaian } \\
\text { dengan benar. }\end{array}$ \\
\hline & $\begin{array}{l}\text { Dapat menjelaskan hubungan antar } \\
\text { langkah satu dengan yang lainnya. }\end{array}$ \\
\hline \multirow[t]{2}{*}{$\begin{array}{l}\text { Melaksanakan } \\
\text { Rencana (carrying } \\
\text { out the plan) }\end{array}$} & $\begin{array}{l}\text { Dapat menggunakan koneksi } \\
\text { antarkonsep dan operasi dalam } \\
\text { matematika }\end{array}$ \\
\hline & $\begin{array}{l}\text { Dapat menggunakan matematika } \\
\text { dalam penyelesaian masalah yang } \\
\text { berkaitan dengan kehidupan sehari- } \\
\text { hari }\end{array}$ \\
\hline \multirow[t]{2}{*}{$\begin{array}{l}\text { Melihat Kembali } \\
\text { (looking back) }\end{array}$} & $\begin{array}{l}\text { Dapat memeriksa keterkaitan antar- } \\
\text { konsep dan prosedur yang telah } \\
\text { digunakan dalam menyelesaikan } \\
\text { masalah }\end{array}$ \\
\hline & $\begin{array}{l}\text { Dapat menjelaskan/menuliskan } \\
\text { kesimpulan dari hasil penyelesaian } \\
\text { yang telah diperoleh }\end{array}$ \\
\hline
\end{tabular}

Data hasil wawancara dianalisis sesuai dengan teknik analisis data kualitatif yang terdiri atas reduksi data, penyajian data, dan penarikan kesimpulan.

Penelitian ini dilakukan pada tanggal 4-11 Februari 2020 di kelas IX MTs Negeri Gresik Tahun Ajaran $2019 / 2020$.

\section{HASIL DAN PEMBAHASAN}

Data hasil penelitian berupa data hasil angket ARP, hasil TPM, dan data wawancara.

\section{Data Hasil Angket ARP}

Angket ARP diberikan kepada 63 siswa yang terdiri atas 32 siswa kelas IX-A dan 28 siswa kelas IX-H. Angket yang sudah diisi oleh 63 siswa tersebut kemudian diskor untuk menentukan kategori tingkat AQ berdasarkan skor ARP sesuai pada Tabel 1. Dari hasil pengategorian tingkat AQ dapat diketahui banyak siswa pada setiap kategori. Siswa yang masuk ke dalam kelompok climbers sebanyak 4 siswa dari kelas IX-A. Siswa yang masuk ke dalam kelompok campers sebanyak 38 siswa terdiri atas 21 siswa dari kelas IX-A dan 17 siswa dari kelas IX-H. Siswa yang masuk ke dalam kelompok quitters sebanyak 3 siswa 
dari kelas IX-H. Dari masing-masing kelompok kemudian dipilih satu siswa dengan pertimbangan skor ARP dan kemampuan komunikasi siswa yang diketahui melalui diskusi dengan guru mitra.

Subjek penelitian ini terdiri atas: 1 subjek climbers, 1 subjek campers, dan 1 subjek quitters beserta kode siswa dalam Tabel 4 di bawah ini.

Tabel 4. Kode Siswa Sebagai Subjek Penelitian

\begin{tabular}{|c|c|c|c|}
\hline Nama & Kode & Skor ARP & Kategori \\
\hline FSZ & SCB & 167 & Climbers \\
\hline NURY & SCM & 125 & Campers \\
\hline ANI & SQT & 54 & Quitters \\
\hline
\end{tabular}

Tiga subjek yang sudah dipilih tersebut kemudian diberikan TPM yang dikerjakan secara individu sedangkan peneliti sebagai pengawas selama subjek tersebut mengerjakan TPM.

\section{Data Hasil TPM dan Wawancara}

TPM terdiri dari satu soal tentang permasalahan seharihari yang berhubungan dengan kesebangunan bangun datar. Selain berkaitan dengan kehidupan sehari-hari, TPM juga berhubungan dengan konsep-konsep matematika yang beragam, diantaranya konsep rasio dan perbandingan, konsep aljabar, dan konsep bangun datar. TPM yang digunakan juga berhubungan dengan ilmu lain yaitu ilmu desain dan ilmu sosial.

Wawancara dilaksanakan 15 menit setelah subjek mengerjakan TPM. Hasil wawancara diperoleh dari pernyataan subjek penelitian ketika menjawab pertanyaan peneliti.

Berdasarkan hasil TPM yang sudah dikerjakan oleh subjek penelitian, subjek climbers dapat menyelesaikan TPM secara jelas, runtut dan menemukan penyelesaian yang tepat. Ketika diwawancarai, subjek climbers menjawab setiap pertanyaan dengan jelas dan yakin. Subjek climbers menceritakan kembali permasalahan pada TPM dengan bahasanya sendiri. Hal ini berarti subjek climbers memenuhi indikator merepresentasikan masalah ke bentuk representasi yang ekuivalen yaitu dalam bentuk verbal.

\begin{tabular}{|c|c|l|}
\hline P-07 & $:$ & $\begin{array}{l}\text { Apakah soal ini sudah berkaitan dengan } \\
\text { kehidupan sehari-hari? }\end{array}$ \\
\hline SCB-07 & $:$ & $\begin{array}{l}\text { Ya kak, Karena berkaitan dengan membuat baju } \\
\text { kak }\end{array}$ \\
\hline P-09 & $:$ & $\begin{array}{l}\text { Oke, kalau begitu apakah soal ini berkaitan } \\
\text { dengan ilmu selain matematika? }\end{array}$ \\
\hline SCB-09 & $:$ & Tidak ada kak \\
\hline P-11 & $:$ & $\begin{array}{l}\text { Konsep apa saja yang kamu gunakan untuk } \\
\text { menyelesaikan soal ini? Beserta alasannya ya } \\
\text { dek. }\end{array}$ \\
\hline SCB-11 & $: \begin{array}{l}\text { Ada kesebangunan kak, kan ada perbandingan } \\
\text { panjang dan lebar. Selain itu, ada perbandingan } \\
\text { juga kak karena ada skala-skalanya, satuan } \\
\text { hitung juga ada yang meter, centimeter gitu. } \\
\text { Lalu ada juga bangun datar lebih khususnya } \\
\text { persegi panjang untuk kainnya itu kak. }\end{array}$ \\
\hline
\end{tabular}

Berdasarkan hasil wawancara di atas, menunjukkan bahwa subjek climbers menyatakan permasalahan yang diberikan pada TPM berkaitan dengan kehidupan seharihari. Selain itu, subjek climbers mengungkapkan bahwa masalah pada TPM diselesaikan dengan menggunakan beberapa konsep matematika di antaranya ialah konsep kesebangunan, konsep perbandingan, konsep satuan, konsep bangun datar (persegi panjang). Namun, masalah pada TPM menurutnya tidak berkaitan dengan ilmu lain. Dalam mengungkapkan langkah-langkah penyelesaian, subjek climbers dapat menjelaskan hubungan antar langkah yang telah disusun.

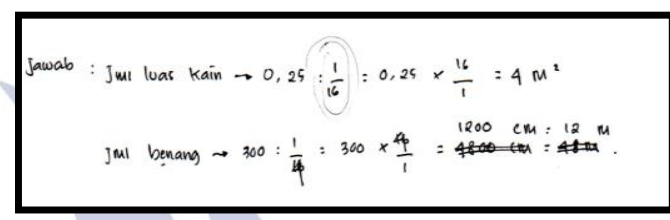

Gambar 1. Hasil TPM Subjek Climbers pada Tahap

Mengecek Kembali

Gambar 1 menunjukkan bahwa subjek climbers melakukan pengecekan kembali sebelum mengumpulkan kepada peneliti. Hal ini ditunjukkan bahwa terdapat coretan pada lembar jawaban dengan tujuan memperbaiki pengerjaan yang salah. Hal tersebut didukung dengan hasil wawancara berikut ini.

\begin{tabular}{|c|c|l|}
\hline P-22 & $:$ & $\begin{array}{l}\text { Sudahkah kamu memeriksanya sebelum } \\
\text { menyerahkan ke saya? }\end{array}$ \\
\hline SCB-22 & $:$ & Sudah kok kak \\
\hline P-23 & $:$ & $\begin{array}{l}\text { Berarti kamu bisa menjelaskan } \\
\text { kesimpulan dari permasalahan ini kan ? }\end{array}$ \\
\hline SCB-23 & $:$ & $\begin{array}{l}\text { Iya kak, jadi biaya produksi untuk 1000 } \\
\text { pesanan baju ialah 100.120.000 rupiah. }\end{array}$ \\
\hline P-24 & $:$ & Kok tidak kamu tuliskan di LJK dek? \\
\hline SCB-24 & $:$ & Oh perlu ditulis ya kak? \\
\hline
\end{tabular}

Hasil wawancara menunjukkan bahwa subjek climbers dapat menyimpulkan hasil pengerjaannya yang telah diperoleh secara tepat meskipun pada hasil TPM tidak menuliskan kesimpulan di dalamnya. Berdasarkan hasil analisis TPM dan wawancara di atas, subjek climbers hampir memenuhi semua indikator kemamapuan koneksi matematis subjek dalam memecahkan masalah. Ia hanya tidak memenuhi satu indikator yaitu menjelaskan konsep disiplin ilmu lain yang berkaitan dengan masalah.

Hasil TPM subjek campers sedikit berbeda dengan hasil TPM subjek climbers. Subjek campers dapat menyelesaikan TPM secara jelas dan runtut namun menemukan penyelesaian yang hampir tepat.

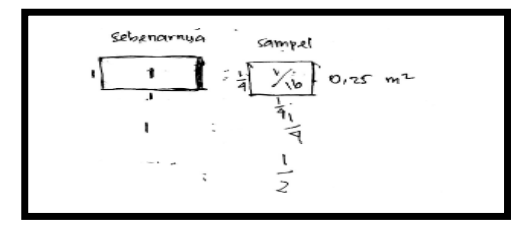

Gambar 2. Hasil Pekerjaan Subjek Campers dalam Memahami Masalah 
Gambar 2 menunjukkan bahwa subjek campers dapat merepresentasikan masalah ke bentuk gambar. Selain itu Pada saat wawancara, subjek campers dapat menceritakan kembali permasalahan pada TPM namun memerlukan waktu sedikit untuk membaca ulang masalah pada lembar TPM. Sehingga dapat disimpulkan bahwa subjek campers dapat merepresentasikan masalah ke dalam representasi yang ekuivalen. Dalam tahap menyusun rencana, hasil TPM tidak memenuhi semua indikator. Namun pada saat wawancara, terdapat beberapa indikator yang terpenuhi. Berikut menunjukkan hasil wawancara dengan subjek campers.

\begin{tabular}{|c|c|l|}
\hline P-12 & $:$ & $\begin{array}{l}\text { kira-kira konsep matematika apa saja } \\
\text { yang untuk } \\
\text { digunakan } \\
\text { menyelesaikan masalah ini? }\end{array}$ \\
\hline SCM-12 & $:$ & Bangun datar dan kesebangunan mbak \\
\hline P-13 & $:$ & $\begin{array}{l}\text { Apakah permasalahan ini berkaitan } \\
\text { dengan kehidupan sehari-hari? }\end{array}$ \\
\hline SCM-13 & $:$ & $\begin{array}{l}\text { Ya, Karena ada produksi baju dan } \\
\text { harga-harganya }\end{array}$ \\
\hline SCM-15 & $:$ & $\begin{array}{l}\text { Selain itu apakah permasalahan ini } \\
\text { berkaitan dengan ilmu lain selain } \\
\text { matematika? Sebutkan jika ada beserta } \\
\text { alasannya }\end{array}$ \\
\hline P-22 & $:$ & $\begin{array}{l}\text { Seni budaya karena ada buat bajunya } \\
\text { dan IPS karena ada harga-harganya }\end{array}$ \\
\hline SCM-22 & $:$ & $\begin{array}{l}\text { Apakah jika langkah-langkah yang } \\
\text { kamu jelaskan tadi itu harus dikerjakan } \\
\text { secara urut? }\end{array}$ \\
\hline
\end{tabular}

Berdasarkan hasil wawancara tersebut, menunjukkan bahwa subjek campers menyatakan permasalahan yang diberikan pada TPM berkaitan dengan kehidupan seharihari. Subjek campers mengungkapkan bahwa masalah pada TPM diselesaikan dengan menggunakan beberapa konsep matematika di antaranya ialah konsep bangun datar (persegi panjang) dan konsep kesebangunan. Selain itu, subjek campers menyatakan bahwa masalah pada TPM berkaitan dengan ilmu lain yaitu Seni Budaya dan IPS. Dalam mengungkapkan langkah-langkah penyelesaian, subjek campers tidak dapat menjelaskan hubungan antar langkah yang telah disusun karena menganggap bahwa langkah yang ia susun harus urut padahal terdapat urutan lain dalam penyelesaiannya.

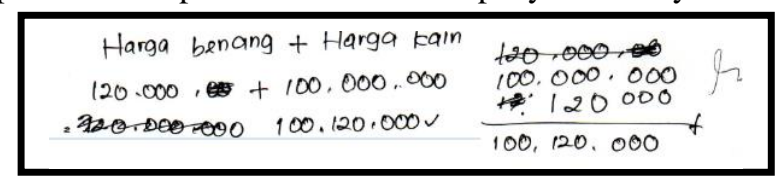

Gambar 3. Hasil Pekerjaan Subjek Campers

Gambar 3 di atas menunjukkan bahwa pada mulanya subjek campers memeroleh hasil yang salah. Namun setelah melakukan perhitungan kembali pada saat wawancara, subjek campers dapat memperbaiki hasil yang diperoleh. Hal ini berarti subjek campers belum melakukan pengecekan kembali pada hasil jawabannya meskipun pada saat wawancara ia dapat menyimpulkan hasil pekerjaannya secara benar. Ketika menjawab setiap pertanyaan yang diajukan oleh peneliti, subjek campers menjawab dengan pasrah, sedikit ragu dan sedikit yakin. Walaupun demikian, subjek campers dapat menyelesaikan wawancara secara tuntas.

Berdasarkan hasil analisis TPM dan wawancara di atas, subjek campers hampir memenuhi semua indikator kemampuan koneksi matematis subjek dalam memecahkan masalah. Ia tidak memenuhi dua indikator yaitu menjelaskan hubungan antar langkah satu dengan yang lainnya dan memeriksa keterkaitan antarkonsep dan prosedur yang telah digunakan dalam menyelesaikan masalah.

Hasil TPM yang dikerjakan oleh subjek quitters menunjukkan bahwa ia telah menyelesaikan permasalahan hingga tuntas meskipun jawaban yang dihasilkan belum benar.

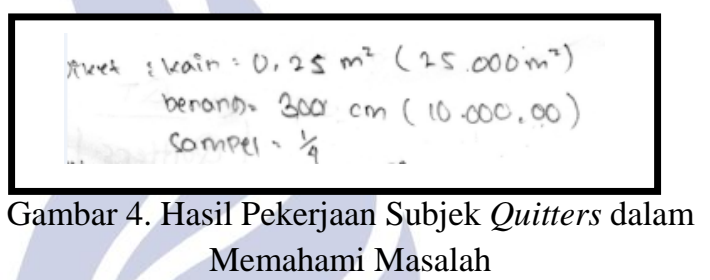

Dari analisis TPM yang dilakukan peneliti pada gambar di atas menunjukkan bahwa subjek quitters belum dapat memahami masalah dengan baik. Subjek melakukan kesalahan dalam menafsirkan permasalahan dalam TPM. Ia mengartikan kalimat "ukuran panjang dan lebar kain yang digunakan pada sampel berturut-turut adalah 1/4 dari panjang dan lebar kain dengan ukuran sebenarnya" sama dengan "skala $1 / 4$ " padahal memiliki maksud yang berbeda. Hal ini mengakibatkan jawaban akhir yang diperoleh subjek quitters belum tepat.

Pada saat proses wawancara, subjek quitters dapat menceritakan kembali masalah namun sedikit mengintip pada lembar TPM dan mengubah makna masalah padahal peneliti sudah memberikan waktu yang cukup untuk membaca ulang masalah. Hal tersebut subjek belum memenuhi indikator merepresentasikan masalah ke bentuk representasi yang ekuivalen.

\begin{tabular}{|c|c|l|}
\hline P-27 & $:$ & $\begin{array}{l}\text { Materi matematika apa saja bisa kamu } \\
\text { gunakan untuk menyelesaikan masalah ini? }\end{array}$ \\
\hline SQT-27 & $:$ & kesebangunan kak \\
\hline P-28 & $:$ & selain itu apakah ada lagi? \\
\hline SQT-29 & $:$ & perbandingan kak \\
\hline P-30 & $:$ & selain itu apakah ada lagi? \\
\hline SQT-30 & $:$ & sepertinya sudah itu saja kak. \\
\hline P-31 & $:$ & $\begin{array}{l}\text { menurut Anita masalah ini berkaitan dengan } \\
\text { ilmu selain matematika tidak? Kalau } \\
\text { memang ada coba jelaskan! }\end{array}$ \\
\hline SQT-31 & $:$ & $\begin{array}{l}\text { ada kak, ilmu tentang desainer kak, IPS juga } \\
\text { ada karena ada harga-harganya. }\end{array}$ \\
\hline P-32 & $:$ & $\begin{array}{l}\text { sip kalau begitu, menurut Anita apakah } \\
\text { masalah ini bisa kita jumpai di kehidupan } \\
\text { sehari-hari? }\end{array}$ \\
\hline SQT-32 & $:$ & \begin{tabular}{l} 
iya kak bisa. \\
\hline
\end{tabular}
\end{tabular}


Berdasarkan hasil wawancara tersebut, menunjukkan bahwa subjek quitters menyatakan permasalahan yang diberikan pada TPM berkaitan dengan kehidupan seharihari. Subjek quitters mengungkapkan bahwa masalah pada TPM diselesaikan dengan menggunakan beberapa konsep matematika di antaranya ialah konsep kesebangunan dan konsep perbandingan. Selain itu, subjek quitters menyatakan bahwa masalah pada TPM berkaitan dengan ilmu lain yaitu ilmu Desainer dan IPS. Dalam mengungkapkan langkah-langkah penyelesaian, subjek quitters tidak dapat menjelaskan hubungan antar langkah yang telah disusun karena dalam mengungkapkan langkah-langkah penyelesaian subjek quitters belum benar. Hal tersebut didukung dengan hasil TPM subjek quitters yang belum benar seperti pada Gambar 5 di bawah ini.

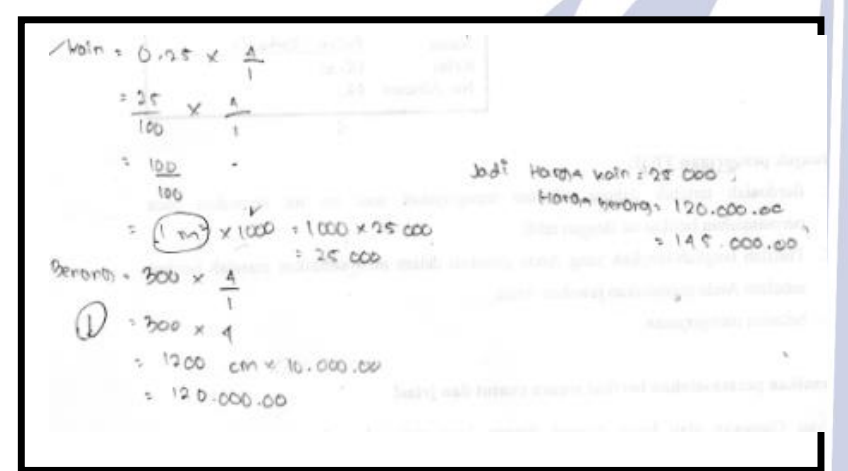

Gambar 5. Hasil Pekerjaan Subjek Quitters dalam Melaksanakan Rencana

Berdasarkan gambar tersebut pula dapat diketahui bahwa subjek quitters tidak melakukan pengecekan keterkaitan antarkonsep dan prosedur yang telah digunakan dalam menyelesaikan masalah dan belum menyimpulkan hasil pekejaannya. Namun ketika proses wawancara, subjek quitters dapat menyimpulkan secara lisan dengan hasil pekerjaan yang benar. Dalam menjawab setiap pertanyaan yang diberikan peneliti, subjek quitters menjawab dengan ragu-ragu, tidak yakin, dan kurang jelas. hal tersebut mengakibatkan proses wawancara berlangsung cukup lama.

Berdasarkan hasil analisis TPM dan wawancara di atas, subjek quitters hampir tidak memenuhi semua indikator kemamapuan koneksi matematis subjek dalam memecahkan masalah. Ia tidak memenuhi lima indikator yaitu merepresentasikan masalah ke bentuk representasi yang ekuivalen, menjelaskan hubungan antar langkah satu dengan yang lainnya, menggunakan koneksi antarkonsep dan operasi dalam matematika, menggunakan matematika dalam penyelesaian masalah yang berkaitan dengan kehidupan sehari-hari, dan memeriksa keterkaitan antarkonsep dan prosedur yang telah digunakan dalam menyelesaikan masalah.

\section{Pembahasan}

Berdasarkan hasil dan analisis yang dilakukan peneliti terhadap hasil TPM dan hasil wawancara, dapat dipaparkan sebagai berikut.

Subjek climbers dapat menyelesaiakan masalah dengan menghasilkan jawaban yang benar dan melakukan semua tahapan pemecahan masalah. Hal ini sejalan dengan penelitian yang dilakukan oleh Irianti (2017) yang menjelaskan bahwa siswa climbers mampu menyelesaikan masalah dengan baik dan melakukan setiap tahap dalam memecahkan masalah. Setiap tahap pemecahan masalah yang dilakukan oleh subjek climbers menggunakan kemampuan koneksi matematis di dalamnya. Berdasarkan pendapat dari Hendriana dkk (2017) kemampuan koneksi matematis berpengaruh dalam mempermudah proses pemecahan masalah. Melalui koneksi matematis siswa lebih mudah membuat representasi yang ekuivalen dengan masalah, kemudian menggunakan ide dan konsep matematika untuk mendapatkan solusi dari suatu masalah. Hal tersebut yang dimiliki oleh siswa climbers dalam memecahkan masalah. Dalam proses pemecahan masalah, siswa climbers secara baik menggunakan koneksi antarkonsep dan prosedur dalam matematika, dapat menjelaskan keterkaitan masalah dengan ilmu selain matematika dan dapat menggunakan matematika dalam menyelesaikan masalah yang berkaitan dengan kehidupan sehiri-hari. Hal ini di dukung pula oleh pendapat Kenedi (2019) yang mengungkapkan bahwa proses pemecahan masalah matematika adalah aktivitas siswa yang dapat membangun koneksi matematis siswa.

Subjek campers juga dapat menyelesaiakn permasalahan dengan jawaban yang benar namun terdapat tahapan pemecahan masalah yang tidak dilaksanakan yaitu pada tahap melihat kembali. Hal tersebut sejalan dengan penelitian yang dilakukan oleh Irianti (2017) yang menjelaskan bahwa siswa campers mampu menyelesaikan masalah dengan cukup baik dan melakukan sebagian besar tahap dalam memecahkan masalah yaitu mulai dari memahami masalah hingga menggunakan langkahlangkah sesuai dengan rencana. Siswa campers tidak melakukan tahap pengecekan kembali sehingga mengakibatkan jawaban yang diperoleh kurang tepat. Hal ini didukung oleh pendapat Nilasari \& Anggreini (2019) yang menyatakan bahwa siswa campers tidak melakukan pemeriksaan kembali terhadap penyelesaian yang telah diperoleh karena merasa sudah puas dengan hasilnya. Perasaan puas inilah yang menjadi ciri khas seseorang yang tergolong pada tingkat AQ campers. Stoltz (2000) memaparkan bahwa seseorang yang tergolong campers dengan mudah merasa puas atas kinerja yang telah ia lakukan. Kepuasan ini juga mengakibatkan siswa campers 
mengalami kegagalan dalam memeriksa keterkaitan antarkonsep dan prosedur yang telah digunakan dalam menyelesaikan masalah. Hal ini di dukung pula oleh pendapat Kenedi (2019) yang mengungkapkan bahwa proses pemecahan masalah matematika harus memiliki kemampuan untuk melakukan keterkaitan konsep atau teorema yang digunakan untuk menyelesaikan suatu masalah.

Subjek quitters tidak dapat menyelesaiakan permasalahan dengan jawaban yang benar dan tidak melakukan sebagian besar tahapan pemecahan masalah dengan sempurna. Hal ini sejalan dengan penelitian yang dilakukan oleh Irianti (2017) yang menjelaskan bahwa siswa quitters dalam menyelesaikan masalah melakukan tahap memahami masalah dan penyusunan rencana secara baik sedangkan pada tahap penyelesaian masalah belum sampai tahap akhir. Subjek quitters tidak menuntaskan tahap melaksanakan rencana dan pengecekan kembali sehingga mengakibatkan jawaban belum memeroleh hasil yang tepat. Hal ini dikarenakan siswa quitters terlalu lama dalam memahami permasalahan yang diberikan dan kurang antusias menjawab pertanyaan peneliti. Didukung oleh pendapat Nilasari \& Anggreini (2019) yang menyatakan bahwa siswa quitters masih ragu-ragu dan belum bisa memberikan alasan yang logis, selain itu tidak bisa menafsirkan kembali pemecahan masalah ke dalam konteks dunia nyata. Keraguan inilah yang menjadi ciri khas seseorang yang tergolong pada tingkat AQ quitters. Stoltz (2000) memaparkan bahwa seseorang yang tergolong quitters mudah menyerah sehingga memiliki daya juang yang rendah untuk menyelesaikan masalah. Perasaan mudah menyerah ini yang mengakibatkan siswa quitters membutuhkan waktu yang lama untuk memahami soal dan ketika ditanya, terkesan tidak menjawab atau ragu-ragu dalam menjawabnya. Karena perasaan tersebut pula yang mengakibatkan siswa quitters kurang dapat memecahkan masalah yang diberikan sehingga berpengaruh terhadap kemampuan koneksi matematis yang dimilikinya. Alasan tersebut juga didukung oleh Firdausi, dkk (2018) yang menyatakan bahwa Apabila siswa tidak memahami suatu konsep maka mereka akan kesulitan untuk menerima konsep selanjutnya, hal ini yang menyebabkan siswa memiliki kemampuan yang rendah dalam mengaitkan antarkonsep dalam matematika

Berdasarkan uraian di atas, menunjukkan bahwa dalam memecahkan masalah matematika, setiap subjek yang memiliki tingkat AQ tinggi (climbers), sedang (campers), dan rendah (quitters) memiliki kemampuan koneksi matematis yang berbeda. Hal ini sependapat dengan Irianti (2017) dalam penelitian yang ia lakukan bahwa setiap tiga tingkatan AQ memiliki ciri tersendiri dalam memecahkan suatu masalah. Hal ini dipengaruhi oleh karakter siswa untuk setiap tingkatan. Yoga (2016) membedakan kepribadian climbers, campers, dan quitters dalam bukunya. Karakter inilah yang kemudian memengaruhi kemampuan koneksi matematis setiap siswa dalam memecahkan masalah. Berdasarkan pembahasan tersebut pula, dapat diketahui bahwa tingkatan Adversity Quotient (AQ) yang dimiliki siswa mempengaruhi kemampuan koneksi matematis siswa dalam memecahkan masalah matematika.

\section{PENUTUP}

\section{Simpulan}

Berdasarkan hasil penelitian dan pembahasan dapat diperoleh simpulan sebagai berikut.

1. Kemampuan Koneksi Matematis Siswa Climbers dalam Memecahkan Masalah Matematika

Dalam memecahkan masalah matematika, siswa climbers dapat memeroleh jawaban yang benar. Siswa climbers dapat merepresentasi masalah ke bentuk representasi ekuivalen dalam memahami masalah secara verbal. Siswa climbers dapat menjelaskan konsep matematika yang berhubungan dengan masalah, hubungan antar langkah satu dengan yang lainnya, dan langkah-langkah penyelesaian masalah dalam menyusun rencana. Namun, siswa climbers tidak dapat menjelaskan konsep disiplin ilmu lain yang berkaitan dengan masalah. Dalam melaksanakan rencana, siswa climbers dapat menggunakan koneksi antarkonsep dan prosedur serta menyelesaikan masalah yang berkaitan dengan kehidupan sehari-hari dengan baik. Dalam tahap melihat kembali, siswa climbers juga dapat memeriksa keterkaitan antarkonsep dan prosedur yang telah digunakan dalam menyelesaikan masalah. Selain itu, siswa climbers juga dapat menyimpulkan hasil penyelesaian yang diperoleh secara lisan.

2. Kemampuan Koneksi Matematis Siswa Campers dalam Memecahkan Masalah Matematika

Dalam memecahkan masalah matematika, siswa campers dapat memeroleh jawaban yang hampir benar. Siswa campers dapat merepresentasi masalah ke bentuk representasi ekuivalen dalam memahami masalah secara verbal dan gambar. Siswa campers dapat menjelaskan konsep matematika yang berhubungan dengan masalah, konsep disiplin ilmu lain, dan langkah-langkah penyelesaian masalah dalam menyusun rencana. Namun, siswa campers tidak dapat menjelaskan hubungan antar langkah satu dengan yang lainnya. Dalam melaksanakan rencana, siswa campers dapat menggunakan koneksi antarkonsep dan prosedur serta menyelesaikan masalah yang berkaitan dengan kehidupan sehari-hari. Dalam tahap melihat 
kembali, siswa campers tidak dapat memeriksa keterkaitan antarkonsep dan prosedur yang telah digunakan dalam menyelesaikan masalah. Namun, siswa campers dapat menyimpulkan hasil penyelesaian yang diperoleh secara lisan.

3. Kemampuan Koneksi Matematis Siswa Quitters dalam Memecahkan Masalah Matematika

Dalam memecahkan masalah matematika, siswa quitters tidak dapat memeroleh jawaban yang benar. Siswa quitters tidak dapat merepresentasi masalah ke bentuk representasi ekuivalen dalam memahami masalah secara verbal. Siswa quitters dapat menjelaskan konsep matematika yang berhubungan dengan masalah, konsep disiplin ilmu lain, dan langkah-langkah penyelesaian masalah dalam menyusun rencana. Namun, siswa quitters tidak dapat menjelaskan hubungan antar langkah satu dengan yang lainnya. Dalam melaksanakan rencana, siswa quitters tidak dapat menggunakan koneksi antarkonsep dan prosedur serta menyelesaikan masalah yang berkaitan dengan kehidupan sehari-hari dengan baik. Dalam tahap melihat kembali, siswa quitters tidak dapat memeriksa keterkaitan antarkonsep dan prosedur yang telah digunakan dalam menyelesaikan masalah. Namun, siswa quitters dapat menyimpulkan hasil penyelesaian yang diperoleh secara lisan.

\section{Saran}

Berdasarkan hasil dan pembahasan yang telah dijelaskan sebelumnya, saran sebagai berikut.

1. Pemberian masalah kepada siswa dapat membantu guru dalam mengidentifikasi kemampuan koneksi matematis siswa, oleh karena itu dalam pembelajaran sangat disarankan untuk menerapkan pembelajaran berbasis masalah.

2. Hasil penelitian menunjukkan bahwa kemampuan koneksi matematis siswa dalam memecahkan masalah berbeda-beda. Perbedaan tersebut harapannya akan dijadikan acuan bagi guru dalam menentukan model pembelajaran yang cocok guna menyeimbangkan perbedaan kemampuan koneksi siswa. Model pembelajaran yang dalam penerapannya membutuhkan diskusi antar siswa untuk mendapat keberhasilan yang sama. Salah satu model pembelajaran yang penerapannya membutuhkan pembagian kelompok dan kegiatannya membutuhkan diskusi ialah pembelajaran kooperatif.

3. Data yang diperoleh pada penelitian ini bersumber dari tiga siswa dengan jenis kelamin sama. Hal tersebut menunjukkan bahwa perlu adanya penelitian lebih lanjut untuk membedakan kemampuan koneksi matematis siswa laki-laki dan perempuan dalam memecahkan masalah ditinjau dari Adversity Quotient.

\section{DAFTAR PUSTAKA}

Chairani, Z. 2016. Metakognisi Siswa dalam Pemecahan Masalah Matematika. Yogyakarta: Deepublish. (diakses secara online pada laman web : https://books.google.co.id/books?id=hAxlDwAAQB $\mathrm{AJ} \&$ printsec $=$ frontcover $\& \mathrm{dq}=$ masalah + matematika \& $\mathrm{hl}=\mathrm{id} \& \mathrm{sa}=\mathrm{X} \& \mathrm{ved}=0$ ahUKEwihyJzHgdfkAhUYXSsK HaasAucQ6AEIKDAA\#v=onepage \&q\&f=false)

Dolores-Flores, dkk. 2018. Exploring mathematical connections of pre-university students through tasks involving rates of change. International Journal of Mathematical Education in Science and Technology, 50(3), 369-389. doi:10.1080/0020739X.2018.1507050.

Fendrik, M. 2019. Pengembangan Kemampuan Koneksi Matematis dan Habbits of Mind pada Siswa. (N. Azizah, Penyunt.) Surabaya, Jawa Timur, Wiyung: Media Sahabat Cendikia.

Firdausi, M., dkk. 2018, Desember. Kemampuan Koneksi Matematis Siswa Sekolah Menengah Pertama Berdasarkan Gaya Kognitif. Jurnal Matematika dan Pembelajaran, 6, 237-249.

Hasan, B. 2019. The Analysis of Students' Critical Thinking Ability with Visualizer-Verbalizer Cognitive style in Mathematics. International Journal of Trends in Mathematics Education Research, 2(3), 142-148.

Hendriana, H., dkk. 2017. Hard Skills dan Soft Skills Matematik Siswa (1 ed.). (N. f. Atif, Penyunt.) Bandung: PT. Refika Aditama.

Hidayat, W. 2018, Maret. Kemampuan Pemecahan masalah Matematis dan Adversity Quontient Siswa SMP Melalui Pembelajaran Open-Ended. Jurnal Nasional Pendidikan Matematika, 2, 109.

Irianti, E. P. 2017. Proses Pemecahan Masalah matematika Siswa berdasarkan Adversity Quontient. Surabaya: Universitas Negeri Surabaya.

Kenedi, A. K. 2019, January. Mathematical Connection of Elementary School Students to Solve Mathematical Problem. Journal of Mathematics Education, 10, 6980.

Mawardhiyah, K., \& Manoy, J. T. 2018. Literasi Matematika Siswa SMP dalam Menyelesaikan Soal Program for International Student Assessment (PISA) Berdasarkan Adversity Quotient (AQ). Mathedunesa, Jurnal Ilmiah Pendidikan Matematika, 7, 638-643.

Megaton, Y., \& Tarmizi. 2010. Pelayanan Konseling Pada Satuan Pendidikan Menengah Jilid II. Jakarta: Grasindo. (diakses secara online pada web : https://books.google.co.id/books?id=zmlzebqso1AC\& $\mathrm{pg}=\mathrm{PA} 48 \& \mathrm{dq}=\mathrm{kecerdasan}+\mathrm{adversity}+\mathrm{quotient} \& \mathrm{hl}=\mathrm{en}$ \&sa=X\&ved=0ahUKEwjqyOnljdTkAhU8_XMBHQ ZOAXwQ6AEIUjAF\#v=onepage $\& \mathrm{q}=\mathrm{jame} \& \mathrm{f}=$ false)

NCTM. 2000. Principles Standards for School Mathematics. Reston: NCTM.INC. 
Nilasari, Nanda Triandanu, \& Anggreini, Dewi. 2019. Kemampuan Literasi Matematika Siswa dalam Menyelesaikan Soal PISA Ditinjau dari Adversity Quotient. Jurnal Elemen, 5, 206-219.

Polya, G. 1973. How to Solve It : A New Aspect of Mathematical Method (1 ed.). New Jersey: Princeton University Press.

Pradika, I. D., dkk. 2019, August. Relational Thinking in Problem Solving Mathematics based on Adversity Quotient and Visual Learning Style. International Journal of Trends in Mathematics Education Research, 2, 161-164.

Putri, H. E. 2017. Pendekatan Concrete-PictorialAbstract (CPA), Kemampuan-Kemampuan Matematis dan Rancangan Pembelajaran. Sumedang, Jawa Barat: UPI Sumedang Press. (diakses secara online pada laman web https://books.google.co.id/books?id=PaWoDwAAQB AJ\&pg=PA28\&dq=kemampuan+koneksi+matematis $\& h l=e n \& s a=X \& v e d=0 a h U K E w j I x M X 9 i 9 T k A h V l H o$ 8KHY0yA2YQ6AEIMDAB\#v=onepage\&q\&f=false)

Sari, I., dkk. 2019, Oktober. Students' Thinking Process in Solving Mathematical Problems in Build Flat Side Spaces of Material Reviewed from Adversity Quotient. Malikussaleh Journal of Mathematics Learning (MJML), 2, 61-67.

Setyaningsih, R., \& Prihatnani, E. 2018. Proses Metakognisi mahasiswaTipe Adversity Quotient (AQ) Quitters dalam Memecahkan Masalah Matematika. Satya Widya, 112-124.
Stoltz, P. G. 1997. Adversity Quotient: Turning Obstacles into Opportunities. Canada: John Wiley \& Sons. (diakses secara online pada laman web : https://books.google.co.id/books?id=xH5Jn9JYPF8C $\&$ printsec $=$ frontcover $\& \mathrm{dq}=$ kecerdasan + adversity + quo tient\&hl=en\&sa=X\&ved=0ahUKEwjqyOnljdTkAhU 8_XMBHQZOAXwQ6AEIWzAG\#v=onepage\&q\&f $=$ false)

Stoltz, P. G. 2000. Adversity Quotient : Mengubah Hambatan Menjadi Peluang. Jakarta: Gramediaa Widiasana Indonesia.

Subchan, dkk. 2018. Buku Guru Matematika untuk SMP/MTs Kelas IX Revisi 2018. Jakarta: Kementerian Pendidikan dan Kebudayaan.

Sudarman. 2011. Proses Berpikir Siswa SMP Berdasarkan Adversity Quotient (AQ) dalam menyelesaikan Masalah Matematika. Surabaya: Prodi S3 Pendidikan Matematika, Pascasarjana, tidak dipublikasikan.

Umami, A. H. 2015. Kemampuan Koneksi Matematika Siswa dalam Pemecahan Masalah Ditinjau dari Gara Kognitif Reflektif-Implusif. Surabaya: Universitas Negeri Surabaya.

Yoga, M. 2016. Adversity Quotiont : Agar Anak Tidak Gampang Menyerah (1 ed.). (F. Hasiem, Penyunt.) Solo: Tinta Medina, Creative Imprint of Tiga Serangkai.

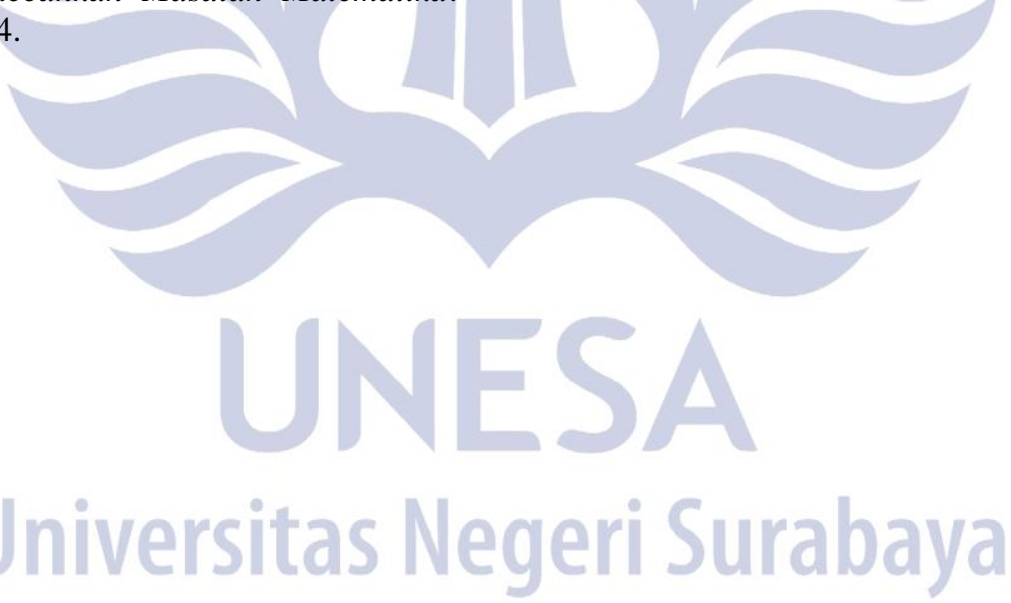

